\title{
Mass Spectrometry Based Proteomic Analysis of Salivary Glands of Urban Malaria Vector Anopheles stephensi
}

\author{
Sonam Vijay, ${ }^{1}$ Manmeet Rawat, ${ }^{1,2}$ and Arun Sharma ${ }^{1}$ \\ ${ }^{1}$ Protein Biochemistry and Structural Biology Laboratory, National Institute of Malaria Research (ICMR), \\ Sector-8, Dwarka, New Delhi 110077, India \\ ${ }^{2}$ Department of Internal Medicine, University of New Mexico School of Medicine, Albuquerque, NM 87106, USA
}

Correspondence should be addressed to Arun Sharma; arushar@gmail.com

Received 18 February 2014; Revised 12 May 2014; Accepted 26 May 2014; Published 14 July 2014

Academic Editor: Franck Remoue

Copyright (C) 2014 Sonam Vijay et al. This is an open access article distributed under the Creative Commons Attribution License, which permits unrestricted use, distribution, and reproduction in any medium, provided the original work is properly cited.

\begin{abstract}
Salivary gland proteins of Anopheles mosquitoes offer attractive targets to understand interactions with sporozoites, blood feeding behavior, homeostasis, and immunological evaluation of malaria vectors and parasite interactions. To date limited studies have been carried out to elucidate salivary proteins of An. stephensi salivary glands. The aim of the present study was to provide detailed analytical attributives of functional salivary gland proteins of urban malaria vector An. stephensi. A proteomic approach combining one-dimensional electrophoresis (1DE), ion trap liquid chromatography mass spectrometry (LC/MS/MS), and computational bioinformatic analysis was adopted to provide the first direct insight into identification and functional characterization of known salivary proteins and novel salivary proteins of An. stephensi. Computational studies by online servers, namely, MASCOT and OMSSA algorithms, identified a total of 36 known salivary proteins and 123 novel proteins analysed by LC/MS/MS. This first report describes a baseline proteomic catalogue of 159 salivary proteins belonging to various categories of signal transduction, regulation of blood coagulation cascade, and various immune and energy pathways of An. stephensi sialotranscriptome by mass spectrometry. Our results may serve as basis to provide a putative functional role of proteins in concept of blood feeding, biting behavior, and other aspects of vector-parasite host interactions for parasite development in anopheline mosquitoes.
\end{abstract}

\section{Background}

Malaria has been prevalent for a long time in tropical developing regions causing great morbidity and mortality [1]. The world malaria report 2013 [1] released by the World Health Organization (WHO) states that an estimated 3.4 billion people are at risk of malaria and around 207 million cases of malaria occurred globally. Among the malaria vectors, An. stephensi is an important urban malaria vector of IndoPakistan subcontinent [2]. Due to susceptible nature of $A n$. stephensi to both human and rodent malaria species, it turns out to be significant to use as a reference laboratory model to study salivary gland-parasite interactions [3]. Salivary glands of mosquitoes perform various functions for survival of the vectors and also are conducive for blood feeding, harbouring of malaria parasites, and eventual parasite transmission. Salivary secretions have various pharmacological substances such as inhibitors of the clotting cascade, inhibitors of vasoconstricting substances, and inhibitors of platelet aggregation, which are necessary for continuous blood feeding in mosquitoes [4].

The salivary gland proteins are thus relevant for malaria research since the Plasmodium sporozoites invade the salivary glands and are injected with the saliva into vertebrate hosts during blood feeding [5]. In addition to this, various other functions are also performed by salivary glands as sugar feeding [6] and blood feeding [4], and some salivary gland proteins show immunogenic properties [7] that help in modulating the immune response of the human host and salivary proteins were found to be annotated in insecticide resistant Culex mosquitoes [8].

Salivary gland tissues of An. stephensi have been studied for molecular and genetic studies and for malaria transmission. Many products of salivary gland gene expression have been studied in An. stephensi with help of applications of transcriptomics and proteomics [3]. However, proteomics 
studies have also been described and roles of some putative salivary proteins were also proposed in evolution of blood feeding and in the discovery of novel antihemostatic substances [3]. However, such An. stephensi sialome studies were elucidated using transcriptomic studies that include full-length cDNA library sequence of An. stephensi $[3,5]$ and during our EST studies on An. stephensi salivary glands $[9,10]$. Though proteomic studies along with transcriptomics studies have been carried out in An. gambiae salivary gland [3] with large number of diverse predicted salivary proteins [11], thus far no comprehensive and detailed functional properties of salivary gland proteins of Anopheles stephensi have been studied. Hence, to fully understand high biological actions of salivary gland proteins and to elucidate their role in different biosynthetic pathways, application of proteomics is very much needed. Mass spectrometry based proteomics data, when applied in conjunction with mosquito salivary gland genomic and transcriptomics databases, provides a comprehensive account that can be used to identify proteins as putative functional components of the salivary glands for novel malaria control strategies [3].

Unfortunately, to date, only limited studies exist to efficiently explore molecular interactions and role of salivary gland proteins of the mosquito and the sporozoites of the Plasmodium parasite. Transcriptomics studies combined with genetic variations across evolutionarily related mosquitoes for targeting specific RNA sequences are generally inconsistent to generate functional proteomic data sets $[3,9,10]$. Gel electrophoresis (1DE) along with mass spectrometry and detailed bioinformatic analysis is a powerful and direct tool to study global protein profiling in tissues. Therefore, as a first step, the aim of the present study was to identify and characterize the protein profiles of An. stephensi salivary gland in order to establish functional phylogeny among different anophelines and other mosquitoes to validate their evolutionary functions.

Here we describe an in-gel proteomic approach using $1 \mathrm{D}$ and LC-MS/MS to characterize the proteome of the salivary gland extracts (SGEs) of An. stephensi. We have achieved this by analyzing mass spectrometry data using MASCOT and OMSSA algorithm. We report, herewith, the catalogue of 159 known and novel proteins obtained from LCMS/MS data through a detailed bioinformatics analysis which should serve as a first preliminary step for putative functional identification of several salivary glands extracts (SGEs) proteins and proteomes at molecular levels that may provide novel targets for interrupting parasitic transmission life cycle. Our study thus opens up the possibilities of elucidating salivary gland-parasite interactions during blood meals and may provide relevant baseline information for characterizing proteomes of other mosquitoes for development of novel vector control strategies.

\section{Materials and Methods}

\subsection{Sample Preparation}

2.1.1. Mosquitoes. Anopheles stephensi mosquitoes reared in our insectary (National Institute of Malaria Research, India) were used in this study. 3-4-day-old sugar fed mosquitoes were used in the experiments and were maintained and reared under identical standard conditions at $27^{\circ} \mathrm{C} \pm 2^{\circ} \mathrm{C}$ with $70 \% \pm 10 \%$ relative humidity and a photoperiod of $12: 12$ (light/dark) hours. Adult mosquitoes were maintained on a $10 \%$ sucrose solution.

2.1.2. Dissection of Salivary Glands. Anopheles stephensi salivary glands were dissected on slide using fine needles under a stereomicroscope at $4 \mathrm{x}$ magnification using phosphatebuffered saline (PBS) and were pooled. After dissection the tissues were immediately placed in a PBS buffer $(100 \mu \mathrm{L})$ with protease inhibitors (Complete, Roche Diagnostics, Germany) and stored at $-80^{\circ} \mathrm{C}$ until use.

2.1.3. Salivary Glands Extract Preparation. A total of 100 pairs of salivary glands of female An. stephensi were used to prepare salivary gland extracts (SGEs). Dissected salivary glands (100 pairs) in PBS were sonicated on ice with three pulses for $20 \mathrm{sec}$. Afterward the suspension was centrifuged for $10 \mathrm{~min}$ at $5000 \mathrm{rpm}$ at $4^{\circ} \mathrm{C}$ to remove cell debris. The extracted supernatant was collected and stored at $-80^{\circ} \mathrm{C}$ for further analysis. Protein estimation was carried out by Lowry's method [12] and analyzed by bovine serum albumin BSA standard curve. The SGEs were stored for in-gel trypsin digestion for further analysis.

\subsection{Sample Analysis}

2.2.1. $1 D$ Gel Electrophoresis (SDS-PAGE). SGE samples were first fractionated on SDS-PAGE for separation. Briefly, 50$75 \mu \mathrm{g}$ of SGE sample was dissolved in sample buffer $(0.625 \mathrm{M}$ Tris $\mathrm{HCl}, 10 \%$ SDS, glycerol, and distilled water) containing $\beta$-mercaptoethanol $(10 \% \mathrm{vol} / \mathrm{vol})$ and heated at $95^{\circ} \mathrm{C}$ for $5 \mathrm{~min} .30 \mu \mathrm{L}$ sample was then loaded onto an acrylamide gel (3\% stacking gel and 10\% resolving gel) and subjected to electrophoresis on a Bio-Rad apparatus (Bio-Rad, USA). Protein molecular weight markers (Genei protein range marker, Bangalore Genei) were also run on the gel. The gel was silver-stained according to the manufacturer's protocol (G-Biosciences). Stained gel was then sliced into different bands and these gel bands were individually subjected to digestion with proteomic grade trypsin (Roche Diagnostics, USA).

2.2.2. In-Gel Protein Digestion before Identification by $L C / M S / M S$. Proteins were reduced, alkylated with iodoacetamide, and digested with trypsin overnight at $37^{\circ} \mathrm{C}$. Briefly, the excised gel slices were subjected to reduction and were dried in a vacuum centrifuge. DTT $(10 \mathrm{mM})$ in ammonium bicarbonate $(100 \mathrm{mM})$ was added to gel pieces and proteins were reduced for 1 hour at $56^{\circ} \mathrm{C}$. After cooling to room temperature reduced proteins were alkylated with IAA $(55 \mathrm{mM})$ in ammonium bicarbonate $(100 \mathrm{mM})$ for $45 \mathrm{~min}$ at $25^{\circ} \mathrm{C}$. After incubation in the dark with occasional vortexing the gel pieces were washed with $50-100 \mu \mathrm{L}$ of ammonium bicarbonate $(100 \mathrm{mM})$ for $10 \mathrm{~min}$, dehydrated by addition of acetonitrile, swelled by rehydration in ammonium bicarbonate $(100 \mathrm{mM})$, and shrunk again by 
addition of the same volume of acetonitrile. After removal of the liquid phase, the gel pieces were completely dried in a vacuum centrifuge. Gel slices were then swollen in a digestion buffer containing ammonium bicarbonate (50 mM), $\mathrm{CaCl}_{2}(5 \mathrm{mM})$, and trypsin solution $(12.5 \mathrm{ng} / \mu \mathrm{L})$ (ratio 1:100) in an ice cold bath. The supernatant was removed after 45 mins and replaced with $5-10 \mu \mathrm{L}$ of the same buffer, but without trypsin, to keep the gel pieces wet during enzymatic cleavage $\left(37^{\circ} \mathrm{C}\right.$, overnight). Peptides were extracted by one change of ammonium bicarbonate $(20 \mathrm{mM})$ and three changes of 5\% formic acid in acetonitrile (50\%) (20 min for each change) at room temperature and dried down. This peptide mixture was then stored for analysis by LC/MS/MS.

\subsection{Instrumentation and Analysis}

2.3.1. $L C / M S / M S$. In-gel digested peptides were analyzed by nano LC-ESI-QTOF-MS/MS on a Bruker micrOTOF-Q II system. For LC-MS/MS analysis $15 \mu \mathrm{L}$ of each sample were injected. Peptides were first trapped and preconcentrated on a C-18 precolumn (Dionex) at $30 \mu \mathrm{L}$ flow for $5 \mathrm{~min}$ and later eluted on the separation column with a flow of $220 \mathrm{~nL} / \mathrm{min}$ (column dimensions were I.D. $75 \mu \mathrm{m}$, length $15 \mathrm{~cm}$, PepMap C-18, $3 \mu \mathrm{m}, 100 \AA$ ). Solvents used for elution of peptides were solvent A: water, $\mathrm{ACN}(1.0 \%)$, and formic acid (0.1\%) and solvent B: ACN and formic acid (0.1\%). All samples were measured in "auto" MS/MS mode, positive ion mode on the Bruker nanospray source with a capillary voltage 1,500 Volts, dry gas flow $6.0 \mathrm{~L} / \mathrm{min}$, dry temperature: $130^{\circ} \mathrm{C}, 1 \mathrm{MS}$ followed by $5 \mathrm{MS} / \mathrm{MS}$ of the most intense ions, total cycle time 4.4$8.8 \mathrm{sec}, \mathrm{m} / z$ 400-1,400 taken as precursor ions for MS/MS, active exclusion after 2 spectra for $0.5 \mathrm{~min}$, and threshold for MS/MS set to 1,000 .

\subsection{Database Search}

MASCOT Server. LC/MS/MS data were analyzed using Bruker Daltonics ProteinScape database system. Raw data were converted into MGF format and database searches were performed on a MASCOT server (MASCOT 2.2, MS/MS Ion Search) using fixed modification (none), variable modification carbamidomethyl (Cys), and me-thionine oxidation for each protein band sample (16 digested samples). Parameters used were trypsin as an enzyme, max missed cleavages: 1, peptide mass tolerance: $\pm 0.05 \mathrm{Da}$ or $10 \mathrm{ppm}$, fragment mass tolerance: $\pm 0.05 \mathrm{Da}$, data format: MASCOT generic, instrument type: ESI-QUAD-TOF, and databases used SwissProt and NCBInr. Searches were made against Anopheles and other mosquito species. All searches were performed as decoy searches; a minimum score of 30 for at least one peptide was required for proteins to be reported. All the protein sequences were compared against the nonredundant database for homology searching through a BLASTP search (http://www.ncbi.nlm.nih.gov/BLAST/Blast.cgi?PAGE=Proteins) and SwissProt. Along with that, protein sequences were also searched against data of An. stephensi peptides present in VectorBase (https://www.vectorbase.org/organisms/anopheles-stephensi/). All identifications were manually validated and the proteins were selected and validated on basis of MOWSE scores, peptides matches, and \% sequence coverage.

OMSSA Server. In order to evaluate other novel proteins which could not be detected with MASCOT, we have also used another search tool, that is, the open mass spectrometry search algorithm (ftp://ftp.ncbi.nih.gov/ pub/lewisg/omssa/CURRENT/), under which probability score was used to determine specificity [13]. Here more spectra were matched as compared to other algorithms. Searches were made against Anopheles gambiae present in the taxonomy list. Almost all the parameters were kept the same for OMSSA as used earlier for MASCOT. All searches were conducted by using database SwissProt and NCBInr like MASCOT and only those peptides were reported as significant for which $E$ value was statistically significant $(E<$ 0.05).

\section{Results and Discussion}

Role of salivary glands and their proteins is important in the mosquito because parasites mature to form infectious sporozoites in salivary glands. Various active protein molecules must be annotated/expressed in salivary glands of mosquito which may help in food ingestion and digestion and facilitate blood feeding, immune defenses, and haemostasis [14]. In earlier studies various genes and their derived proteins have been studied in salivary glands of sugar fed An. stephensi by transcriptomics $[3,10]$. Transcriptomics studies also identified transcripts and genes that may or may not be expressed at the protein level as some may be transcribed as nonfunctional sequences resembling functional genes. Proteomics studies however identify proteins directly and the corresponding genomic sequences can be designated as a protein-coding region. No attempts, however, have been made to study the detailed proteome of An. stephensi salivary glands for functional identification of such proteins.

Mass-spectrometry-based proteomics is now a powerful and reliable method that allows characterization of protein assemblies, and when this is combined with molecular, cellular, and bioinformatics techniques it provides a framework for translating complex molecules into simple molecules for indepth analysis of expressed proteomes $[15,16]$. Therefore, the goal of this study was to identify total salivary gland proteins of An. stephensi expressed by proteome analysis coupled with LC/MS/MS as an initial step towards the cataloging of the hundreds of proteins and peptides in the salivary proteome for future use in blood feeding experiments. The peak list/spectra obtained after LC/MS/MS were analyzed by both MASCOT (Matrix Science) and OMSSA algorithm and matched against databases of Anopheles, Aedes, and Culex mosquito species.

\subsection{Mass Spectrometry-Based In-Gel Digested Sample Analysis}

3.1.1. MASCOT Algorithm. Availability of genome sequence for mosquito An. gambiae has led us to large-scale EST projects to identify potential genes and transcriptomes ex-pressed in different mosquito tissues following blood 
TABLE 1: A catalogue of known proteins identified by using in-gel digestion strategy and LC/MS/MS using MASCOT algorithm.

\begin{tabular}{|c|c|c|c|c|c|c|c|c|}
\hline $\begin{array}{l}\text { S. } \\
\text { number }\end{array}$ & $\begin{array}{c}\text { Accession } \\
\text { number/vector } \\
\text { base accession } \\
\text { number }\end{array}$ & Protein & $\begin{array}{l}\text { Band } \\
\text { number }\end{array}$ & $\begin{array}{l}\text { Mol. } \\
\text { weight }\end{array}$ & Peptides & $\begin{array}{l}\text { Calculated } \\
\text { pI }\end{array}$ & $\begin{array}{l}\text { Sequence } \\
\text { coverage }\end{array}$ & Domain/function \\
\hline 1 & gi: 37201975 & GE rich salivary protein & 16 & 15214 & 8 & 5.15 & $56 \%$ & No conserved domain \\
\hline 2 & gi: 15718081 & D7 protein & 11 & 36396 & 14 & 8.79 & $34 \%$ & $\begin{array}{c}\text { Protein } \\
\text { binding/glycoprotein }\end{array}$ \\
\hline 3 & gi: 29501536 & $\begin{array}{l}\text { SG1D salivary protein } \\
\text { precursor }\end{array}$ & 7 & 46811 & 10 & 9.38 & $23 \%$ & No conserved domain \\
\hline 4 & ASTM013042-PA & $\begin{array}{l}\text { G1 family long form } \\
\text { salivary protein } 3\end{array}$ & 7 & 45829 & 9 & 6.85 & $22 \%$ & No conserved domain \\
\hline 5 & gi: 27372941 & $\begin{array}{l}\text { Putative salivary protein } \\
\text { SG1C }\end{array}$ & 7 & 44292 & 8 & 6.73 & $16 \%$ & No conserved domain \\
\hline 6 & gi: 27372911 & Salivary apyrase & 4 & 64248 & 8 & 6.77 & $12 \%$ & No conserved domain \\
\hline 7 & ASTM006960-PA & Alpha amylase & 3 & 67923 & 2 & 5.27 & $4 \%$ & $\begin{array}{c}\text { Alpha amylase } \\
\text { domain/catalytic activity }\end{array}$ \\
\hline 8 & ASTM007102-PA & Salivary peroxidase & 3 & 67504 & 6 & 8.75 & $10 \%$ & $\begin{array}{c}\text { Heme } \\
\text { binding/peroxidase } \\
\text { activity }\end{array}$ \\
\hline 9 & gi: 27372939 & $\begin{array}{l}\text { Putative salivary protein } \\
\text { SG1A }\end{array}$ & 15 & 19725 & 2 & 4.94 & $11 \%$ & $\begin{array}{l}\text { Nucleotide transport } \\
\text { and metabolism }\end{array}$ \\
\hline 10 & gi: 27372929 & $\begin{array}{l}\text { Putative salivary protein } \\
\text { SG1B }\end{array}$ & 6 & 48120 & 2 & - & $4 \%$ & No conserved domain \\
\hline 11 & gi: 29501376 & $\begin{array}{l}\text { Short D7-4 salivary } \\
\text { protein precursor }\end{array}$ & 15 & 18412 & 1 & - & $7 \%$ & No conserved domain \\
\hline 12 & gi: 27372895 & $\begin{array}{l}\text { Salivary antigen- } 5 \\
\text { related protein }\end{array}$ & 14 & 28974 & 2 & 9.05 & $8 \%$ & $\begin{array}{c}\text { CTD-interacting } \\
\text { domain (polypeptide } \\
\text { binding) }\end{array}$ \\
\hline 13 & gi: 29501528 & $\begin{array}{l}\text { TRIO salivary gland } \\
\text { protein precursor }\end{array}$ & 7 & 44013 & 3 & 7.01 & $3 \%$ & $\begin{array}{l}\text { SCP-like extracellular } \\
\text { protein domain }\end{array}$ \\
\hline
\end{tabular}

meal. These EST projects are no doubt descriptive in nature and generate hypothesis on the evolution and function of genes [9]. Still that kind of analysis may identify abundant transcripts which might not be expressed at the protein level. However, if we directly identify and characterize a protein, the corresponding genomic transcript can be automatically designated as a protein-coding region.

In the present study, we employed a MS-based approach to categorize different putative functional proteins of salivary glands of an urban malaria vector An. stephensi of India. Total proteins of the salivary glands homogenate were first analyzed by in-gel approach on $10 \%$ SDS-PAGE. 16 gel bands of salivary gland homogenate sample were visualized after silver staining (Figure 1). In-gel digested peptides of An. stephensi salivary gland were then analyzed by LC/MS/MS. 36 known proteins and 12 novel proteins were identified by MASCOT algorithm. Some known salivary proteins and novel proteins and their details like molecular weight, peptides number, calculated pI, sequence coverage, and domain information are depicted in tables (Tables 1 and 2). Other known proteins are presented in supporting information (in Supplementary Material available online at http://dx.doi.org/10.1155/2014/686319).

Different proteins are also assigned according to gel bands. In Table 1 (including additional Table 1) 3 proteins are identified from band 2, 3 proteins from band 3, 1 protein from band 4, 2 proteins from band 5, 3 proteins from band 6, 4 proteins from band 7, 3 proteins from band 8,1 protein from band 11, 1 protein from band 13, 4 proteins from band 14, 4 proteins from band 15 , and 4 proteins from band 16 . Same as in Table 2, 1 protein is identified from band 1, 1 protein from band 2, 1 protein from band 4, 1 protein from band 5, 1 protein from band 7, 2 proteins from band 13, 1 protein from band 14,1 protein from band 15 , and 4 proteins from band 16. These proteins with band number are given in respective tables (Tables 1 and 2).

Among all identified proteins by LC/MS/MS, further conserved domains were searched by using NCBI domain programs (www.ncbi.nlm.nih.gov/Structure/cdd/wrpsb.cgi) [17], Interproscan analysis and also predicted by SMART programme (http://smart.embl-heidelberg.de/) [18]. Signal peptides were also identified at the $\mathrm{N}$-terminus of all identified proteins with the help of SignalP 4.1 (http://www.cbs.dtu.dk/ services/SignalP/) which shows the indication of secretion [19].

Among the known proteins, GE rich salivary gland protein was found with $56 \%$ sequence similarity with the highest score (609) and a total of 8 peptide matches. Further signal peptide for GE rich salivary gland protein was identified at amino acid positions 1 to 19 which depicts a secreted protein 
TABLE 2: A catalogue of novel proteins identified by using in-gel digestion strategy and LC/MS/MS using MASCOT algorithm.

\begin{tabular}{|c|c|c|c|c|c|c|c|c|}
\hline $\begin{array}{l}\text { S. } \\
\text { number }\end{array}$ & $\begin{array}{c}\text { Accession } \\
\text { number }\end{array}$ & Protein & $\begin{array}{c}\text { Band } \\
\text { number }\end{array}$ & $\begin{array}{c}\text { Mol. } \\
\text { weight }\end{array}$ & Peptides & $\begin{array}{c}\text { Calculated } \\
\text { pI }\end{array}$ & $\begin{array}{l}\text { Sequence } \\
\text { coverage }\end{array}$ & Domain/function \\
\hline 1 & gi: 94468834 & $\begin{array}{c}\text { FOF1-type ATP synthase } \\
\text { beta subunit (similar to } \\
\text { Aedes aegypti) }\end{array}$ & 5 & 53937 & 16 & 5.03 & $22 \%$ & $\begin{array}{l}\text { Nucleotide-binding } \\
\text { domain }\end{array}$ \\
\hline 2 & gi: 170059752 & $\begin{array}{l}\text { Histone } \mathrm{H} 4 \text { (similar to } \\
\text { Culex quinquefasciatus) }\end{array}$ & 16 & 11374 & 2 & 11.36 & $21 \%$ & Nucleosome assembly \\
\hline 3 & gi: 118784826 & $\begin{array}{l}\text { AGAP005078-PA } \\
\text { (similar to Anopheles } \\
\text { gambiae str. PEST) }\end{array}$ & 16 & 13032 & 2 & 11.16 & $13 \%$ & No conserved domain \\
\hline 4 & gi: 347963754 & $\begin{array}{l}\text { AGAP000403-PA } \\
\text { (similar to Anopheles } \\
\text { gambiae str. PEST) }\end{array}$ & 15 & 19831 & 1 & 10.37 & $6 \%$ & Nucleotide binding \\
\hline 5 & gi: 356578763 & $\begin{array}{c}\text { Copper/zinc superoxide } \\
\text { dismutase } 3 \mathrm{~B} \text { (similar to } \\
\text { An. aquasalis) }\end{array}$ & 16 & 15646 & 1 & 5.94 & $6 \%$ & Ion binding \\
\hline 6 & gi: 118782571 & $\begin{array}{l}\text { AGAP002575-PA } \\
\text { (similar to Anopheles } \\
\text { gambiae str. PEST) }\end{array}$ & 14 & 27619 & 1 & 5.03 & $3 \%$ & Leucine rich repeats \\
\hline 7 & gi: 129716442 & $\begin{array}{l}\text { Rps7 (fragment) OS } \\
\text { similar to Anopheles } \\
\text { funestus }\end{array}$ & 16 & 15374 & 1 & 9.85 & $3 \%$ & Translation \\
\hline 8 & gi: 122116875 & $\begin{array}{c}\text { Molybdenum cofactor } \\
\text { sulfurase } 2 \text { (similar to } \\
\text { Aedes aegypti) }\end{array}$ & 2 & 85615 & 2 & 6.76 & $3 \%$ & $\begin{array}{c}\text { Pyridoxal phosphate- } \\
\text { (PLP-) dependent } \\
\text { enzymes }\end{array}$ \\
\hline 9 & gi: 158285167 & $\begin{array}{c}\text { AGAP007706-PA } \\
\text { (kinesin-like protein) }\end{array}$ & 1 & 99191 & 3 & 9.2 & $2 \%$ & ATP activity \\
\hline 10 & gi: 158299522 & $\begin{array}{l}\text { Tetraspanin protein } \\
\text { (similar to Anopheles } \\
\text { gambiae str. PEST) }\end{array}$ & 13 & 29075 & 1 & 8.96 & $2 \%$ & No conserved domain \\
\hline 11 & gi: 58391886 & $\begin{array}{l}\text { AGAP009833-PA } \\
\text { (similar to Anopheles } \\
\text { gambiae str. PEST) }\end{array}$ & 13 & 30740 & 2 & 8.64 & $2 \%$ & Porin \\
\hline 12 & gi: 170037149 & $\begin{array}{l}\text { Apoptosis inhibitor } \\
\text { (similar to Culex } \\
\text { quinquefasciatus) }\end{array}$ & 4 & 61233 & 2 & 6.46 & $1 \%$ & No conserved domain \\
\hline
\end{tabular}

(Figure 2(a)). Next to that D7 protein of score 587 with 14 peptide matches and significant threshold was identified with $34 \%$ sequence similarity. Others are like SG1D salivary protein precursor with 10 peptide matches (23\%) and G1 family long salivary protein 3 ( $22 \%$ sequence similarity).

A sort of salivary gland proteins termed as SG1 family [20, 21] was identified with 11 to $23 \%$ sequence coverage. Signal peptide was identified among SG1 family. The position of signal peptide for SG1D salivary protein was identified at 1-24 (Figure 2(b)) and similarly for putative salivary protein SG1C 1 to 22 and putative salivary protein SG1A 1 to 26. Even earlier transcriptomics studies in An. stephensi also revealed about 9 cDNA clusters similarities to An. gambiae SG1 proteins family [3]. Valenzuela et al. also depicted five full-length sequences in An. stephensi that were related to different clusters of SG1 family [3] and a similar protein was identified in proteomic studies by LC/MS/MS analysis (SG1A, SG1B, SG1C, and SG1D) (Table 1). Other groups of proteins were identified which have secreted function like salivary apyrase (signal peptide at 1 to 27 position) and salivary antigen -5 related protein (signal peptide at 1 to 21 amino acid position).

13 novel hypothetical proteins were identified by MASCOT analysis that has features similar to proteins in other mosquito species like An. gambiae, Aedes aegypti, Anopheles funestus, and Culex quinquefasciatus (Table 2). One novel hypothetical protein identified was found similar to Aedes aegypti FOF1-type ATP synthase beta subunit with 16 peptide matches and $22 \%$ sequence similarity. Another protein identified was similar to Histone $\mathrm{H} 4$ of Culex quinquefasciatus $(21 \%)$. One novel protein was found to be similar to tetraspanin of An. gambiae (signal peptide at position 1 
TABLE 3: A catalogue of novel proteins identified by using in-gel digestion strategy and LC/MS/MS using OMSSA algorithm.

\begin{tabular}{|c|c|c|c|c|c|c|}
\hline $\begin{array}{l}\text { S. } \\
\text { number }\end{array}$ & Accession & Features & MW & $\begin{array}{c}\% \text { Seq } \\
\text { coverage }\end{array}$ & $E$ value & Domain \\
\hline 1 & gi: 224037899 & Gambicin (similar to Anopheles gambiae) & 3373.62 & $38 \%$ & 0.02 & No conserved domain \\
\hline 2 & gi: 126680249 & Unknown (similar to Anopheles gambiae) & 5546.78 & $34 \%$ & 0.02 & No conserved domain \\
\hline 3 & gi: 53771806 & $\begin{array}{l}\text { Glutaredoxin (similar to Anopheles } \\
\text { gambiae) }\end{array}$ & 1932.89 & $34 \%$ & 0.005 & GRX domain \\
\hline 4 & gi: 126680357 & Unknown (similar to Anopheles gambiae) & 3266.66 & $33 \%$ & 0.045 & No conserved domain \\
\hline 5 & gi: 187440102 & $\begin{array}{l}\text { CLIPB7 protein (similar to Anopheles } \\
\text { gambiae) }\end{array}$ & 4640.28 & $31 \%$ & 0.01 & Clip domain \\
\hline 6 & gi: 31281916 & $\begin{array}{l}\text { Xanthine dehydrogenase (similar to } \\
\text { Anopheles gambiae) }\end{array}$ & 1641.8 & $29 \%$ & 0.05 & $\begin{array}{l}\text { Fe-S cluster binding } \\
\text { domain }\end{array}$ \\
\hline 7 & gi: 37576232 & $\begin{array}{l}\text { Defender against programmed cell death } \\
\text { (similar to Anopheles gambiae) }\end{array}$ & 3491.73 & $28 \%$ & 0.05 & Integral membrane protein \\
\hline 8 & gi: 5834921 & $\begin{array}{l}\text { ND4L gene product (mitochondrion) } \\
\text { (similar to Anopheles gambiae) }\end{array}$ & 3456.69 & $28 \%$ & 0.01 & Oxidoreductases \\
\hline 9 & gi: 54124659 & $\begin{array}{l}\text { Peroxidase } 12 \text { (similar to Anopheles } \\
\text { gambiae) }\end{array}$ & 3793.88 & $27 \%$ & 0.009 & Peroxidase domain \\
\hline 10 & gi: 187440702 & $\begin{array}{l}\text { GNBPB1 protein (similar to Anopheles } \\
\text { gambiae) }\end{array}$ & 3776.06 & $26 \%$ & 0.02 & No conserved domain \\
\hline 11 & gi: 87080401 & $\begin{array}{l}\text { Putative TIL domain polypeptide (similar } \\
\text { to Anopheles gambiae) }\end{array}$ & 3276.31 & $25 \%$ & 0.03 & $\begin{array}{l}\text { Trypsin inhibitor-like } \\
\text { cysteine rich domain }\end{array}$ \\
\hline 12 & gi: 3139135 & Defensin (similar to Anopheles gambiae) & 2263 & $23 \%$ & 0.004 & Defensin superfamily \\
\hline 13 & gi: 54124633 & $\begin{array}{l}\text { Peroxidase } 1 \text { (similar to Anopheles } \\
\text { gambiae) }\end{array}$ & 1978.95 & $23 \%$ & 0.02 & Animal heme peroxidases \\
\hline 14 & gi: 281186343 & $\begin{array}{l}\text { Peptidoglycan recognition protein } 3 \text { short } \\
\text { class (similar to Anopheles gambiae) }\end{array}$ & 4460.29 & $22 \%$ & 0.002 & $\begin{array}{l}\text { Pattern recognition } \\
\text { receptor }\end{array}$ \\
\hline 15 & gi: 18139597 & $\begin{array}{l}\text { Cytochrome P450 CYP4C28 (similar to } \\
\text { Anopheles gambiae) }\end{array}$ & 3816.62 & $22 \%$ & 0.01 & cypX domain \\
\hline 16 & gi: 187340440 & $\begin{array}{l}\text { PGRPS1 protein (similar to Anopheles } \\
\text { gambiae) }\end{array}$ & 1596.76 & $21 \%$ & 0.001 & $\begin{array}{l}\text { Peptidoglycan recognition } \\
\text { proteins (PGRPs) }\end{array}$ \\
\hline 17 & gi: 7716428 & $\begin{array}{l}\text { Thioredoxin } 1 \text { (similar to Anopheles } \\
\text { gambiae) }\end{array}$ & 2425.01 & $21 \%$ & 0.02 & TRX domain \\
\hline 18 & gi: 37677930 & agCP14332 (similar to Anopheles gambiae) & 2083.04 & $21 \%$ & 0.001 & No conserved domain \\
\hline 19 & gi: 158452713 & $\begin{array}{l}\text { Caspase short class, partial (similar to } \\
\text { Anopheles gambiae) }\end{array}$ & 1869.74 & $21 \%$ & 0.038 & No conserved domain \\
\hline 20 & gi: 48994192 & $\begin{array}{l}\text { Putative odorant-binding protein OBPjj9 } \\
\text { (similar to Anopheles gambiae) }\end{array}$ & 3964.71 & $20 \%$ & 0.02 & Olfactory receptor, OBP \\
\hline 21 & gi: 6635469 & $\begin{array}{l}\text { Immune-responsive trypsin-like serine } \\
\text { protease-related protein ISPR10 (similar } \\
\text { to Anopheles gambiae) }\end{array}$ & 2705.24 & $20 \%$ & 0.004 & No conserved domain \\
\hline 22 & gi: 187441150 & $\begin{array}{l}\text { SCRB2 protein (similar to Anopheles } \\
\text { gambiae) }\end{array}$ & 2410.2 & $19 \%$ & 0.05 & Scavenger receptor \\
\hline 23 & gi: 40019419 & $\begin{array}{l}\text { Odorant-binding protein OBP5 } 470 \\
\text { (similar to Anopheles gambiae) }\end{array}$ & 3655.7 & $18 \%$ & 0.01 & No conserved domain \\
\hline 24 & gi: 28396160 & $\begin{array}{l}\text { Putative antennal carrier protein AP-1 } \\
\text { (similar to Anopheles gambiae) }\end{array}$ & 2793.37 & $18 \%$ & 0.03 & No conserved domain \\
\hline 25 & gi: 310756184 & $\begin{array}{l}\text { AGAP005196 (similar to Anopheles } \\
\text { gambiae) }\end{array}$ & 2911.43 & $18 \%$ & 0.02 & Tryp_SPc domain \\
\hline 26 & gi: 13509402 & $\begin{array}{l}\text { Hypothetical protein (similar to } \\
\text { Anopheles gambiae) }\end{array}$ & 2117 & $18 \%$ & 0.02 & No conserved domain \\
\hline 27 & gi: 37703114 & $\begin{array}{l}\text { Odorant receptor } 1 \text { (similar to Anopheles } \\
\text { gambiae) }\end{array}$ & 4085.1 & $17 \%$ & 0.002 & Transmembrane receptor \\
\hline 28 & gi: 187441612 & $\begin{array}{l}\text { TEP2 protein (similar to Anopheles } \\
\text { gambiae) }\end{array}$ & 3276.31 & $16 \%$ & 0.03 & Terpene cyclases domain \\
\hline
\end{tabular}


TABLe 3: Continued.

\begin{tabular}{|c|c|c|c|c|c|c|}
\hline $\begin{array}{l}\text { S. } \\
\text { number }\end{array}$ & Accession & Features & MW & $\begin{array}{l}\% \text { Seq } \\
\text { coverage }\end{array}$ & $E$ value & Domain \\
\hline 29 & gi: 2564570 & $\begin{array}{l}\text { NADH dehydrogenase subunit } 5 \text { (similar } \\
\text { to Anopheles gambiae) }\end{array}$ & 4157.12 & $16 \%$ & 0.003 & Ubiquitin/PQ complex \\
\hline 30 & gi: 187440738 & $\begin{array}{l}\text { CLIPB13 protein (similar to Anopheles } \\
\text { gambiae) }\end{array}$ & 2515.41 & $14 \%$ & 0.05 & Trypsin like serine protease \\
\hline 31 & gi: 311985 & $\begin{array}{l}\text { ANG12 precursor (similar to Anopheles } \\
\text { gambiae) }\end{array}$ & 3171.52 & $14 \%$ & 0.06 & $\begin{array}{l}\text { Insect allergen related } \\
\text { repeat }\end{array}$ \\
\hline 32 & gi: 187441890 & $\begin{array}{l}\text { SCRBQ2 protein (similar to Anopheles } \\
\text { gambiae) }\end{array}$ & 2356.32 & $14 \%$ & 0.001 & CD36 family \\
\hline 33 & gi: 187444412 & $\begin{array}{l}\text { FBN9 protein (similar to Anopheles } \\
\text { gambiae) }\end{array}$ & 2425.3 & $14 \%$ & 0.01 & No conserved domain \\
\hline 34 & gi: 1495237 & $\begin{array}{l}\text { GSTD2 protein (similar to Anopheles } \\
\text { gambiae) }\end{array}$ & 3391.77 & $14 \%$ & 0.005 & $\begin{array}{l}\alpha \text { helical domain GS } \\
\text { transferases }\end{array}$ \\
\hline 35 & gi: 1369924 & $\begin{array}{l}\text { Immune factor (similar to Anopheles } \\
\text { gambiae) }\end{array}$ & 2675.3 & $13 \%$ & 0.07 & Rel homology domain \\
\hline 36 & gi: 19071278 & $\begin{array}{l}\text { Odorant-binding protein (similar to } \\
\text { Anopheles gambiae) }\end{array}$ & 2129.03 & $13 \%$ & 0.06 & Olfactory receptor \\
\hline 37 & gi: 117957967 & $\begin{array}{l}\text { Beta carbonic anhydrase (similar to } \\
\text { Anopheles gambiae) }\end{array}$ & 3784.98 & $13 \%$ & 0.008 & $\begin{array}{l}\text { Carbonic anhydrase } \\
\text { domain }\end{array}$ \\
\hline 38 & gi: 33355867 & $\begin{array}{l}\text { Odorant-binding protein AgamOBP52 } \\
\text { (similar to Anopheles gambiae) }\end{array}$ & 2645.31 & $13 \%$ & 0.002 & No conserved domain \\
\hline 39 & gi: 12007372 & $\begin{array}{l}\text { Glutathione S-transferase E1 (similar to } \\
\text { Anopheles gambiae) }\end{array}$ & 2884.43 & $12 \%$ & 0.001 & GSTC Delta epsilon \\
\hline 40 & gi: 1245442 & $\begin{array}{l}\text { Putative arylphorin precursor, partial } \\
\text { (similar to Anopheles gambiae) }\end{array}$ & 2681.36 & $11 \%$ & 0.02 & Copper containing protein \\
\hline 41 & gi: 240270034 & $\begin{array}{l}\text { Serpin } 7 \text { inhibitory serine protease } \\
\text { inhibitor (similar to Anopheles gambiae) }\end{array}$ & 3358.47 & $11 \%$ & 0.002 & Proteinase inhibitors \\
\hline 42 & gi: 157042594 & $\begin{array}{l}\text { suppressor of cytokine signaling } 5 \\
\text { (similar to Anopheles gambiae) }\end{array}$ & 2507.2 & $11 \%$ & 0.03 & SH2 domains \\
\hline 43 & gi: 169260669 & Vasa (similar to Anopheles gambiae) & 1458.78 & $11 \%$ & 0.03 & $\begin{array}{l}\text { Helicase } \mathrm{C} \text { terminal } \\
\text { domain }\end{array}$ \\
\hline 44 & gi: 71841593 & $\begin{array}{l}\text { pk-1 receptor (similar to Anopheles } \\
\text { gambiae) }\end{array}$ & 4041.93 & $11 \%$ & 0.001 & G protein coupled receptor \\
\hline 45 & gi: 853701 & $\begin{array}{l}\text { Serine proteinase (similar to Anopheles } \\
\text { gambiae) }\end{array}$ & 2735.34 & $11 \%$ & 0.02 & Trypsin-like serine protease \\
\hline 46 & gi: 1256440 & $\begin{array}{l}\text { Hexamerin (similar to Anopheles } \\
\text { gambiae) }\end{array}$ & 3847.48 & $5 \%$ & 0.03 & $\begin{array}{l}\text { Hemocyanin Ig-like } \\
\text { domain }\end{array}$ \\
\hline
\end{tabular}

* OMSSA: open mass spectrometry search algorithm.

to 33). This protein was well studied in Drosophila which is a conserved membrane protein and it was known to be involved in intracellular signaling and cellular motility [22].

3.1.2. OMSSA Algorithm. All 16 digested samples were also analyzed by OMSSA algorithm after MS/MS analysis (ftp://ftp.ncbi.nih.gov/pub/lewisg/omssa/CURRENT/) by matching sequences of An. gambiae present in the database. We have identified and chosen only significant novel proteins matches on basis of $E$ value. A total of 111 novel proteins from both SwissProt and NCBI nonredundant protein entries were identified by OMSSA algorithm. Information like molecular weight, \% sequence coverage, and domain information of some putative functional significant proteins is depicted in Table 3. Other novel proteins are presented in supporting information. Many proteins were identified similar to gambicin $(38 \%)$, glutaredoxin protein $(34 \%$ sequence similarity), peroxidase 1 (23\%), unknown protein $(34 \%)$, CLIPB7 (31\%), defender against apoptosis (28\%), defensin $(23 \%)$, peptidoglycan recognition protein $3(22 \%)$, and so forth.

During LC/MS/MS analysis, one of the peptides eluted with an amino acid sequence NWATSGETVDECLEEMAGSACEQAYFFTRCVMTR was matched to putative odorantbinding protein OBPjj9 (Anopheles gambiae) that was analyzed by both $b$ and y type ions. Signal peptide of this protein was identified at position 1 to 29 and $20 \%$ similarity was found. Many other proteins were also identified that have secreted function like defensin (signal peptide at position 1 to 25) and lysozyme c6 and protein O-fucosyltransferase 1 (signal peptide position for both was at 1 to 17 ). 


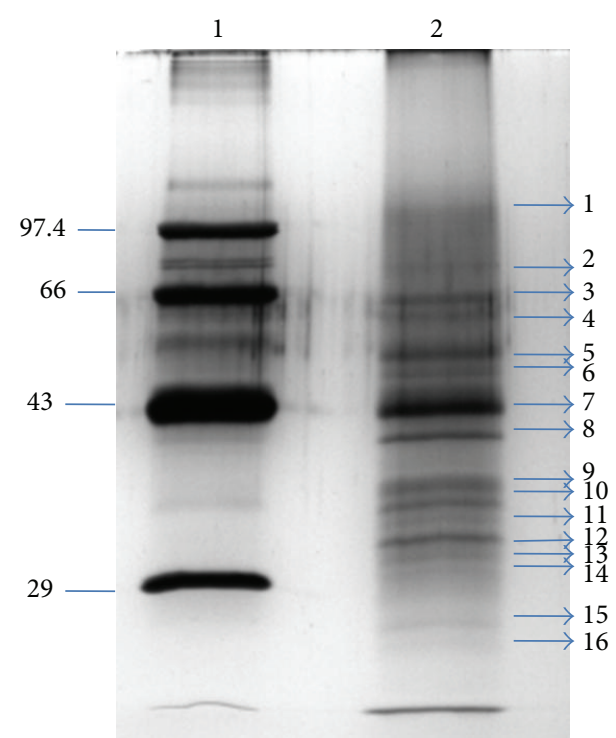

FIGURE 1: Salivary gland protein profiling of An. stephensi. Silver stained SDS-PAGE gel of the salivary gland extract is shown (lane 2). Protein markers with range 14 to $100 \mathrm{kDa}$ are shown in lane 1.

Another peptide with amino acid sequence LMTYFDYFDSDVSNVLPMQSTDKYFDYAVFAR was identified, that is, hexamerin, with signal peptide at position 1 to 18 (Figure 3(a)). A peptide sequence MNFFIKQLAIADLCVGLLNVLTDIIWR was identified similar to protein designated as G-protein coupled receptor in An. gambiae with peak spectrum at $m / z 638$ (Figure 3(b)).

\subsection{Functional Significance of Identified Salivary Proteins.} A total of 36 known proteins and 123 novel proteins were identified from both MASCOT and OMSSA algorithm. Putative functional annotation according to both biological approach and cellular approach was prepared among the identified proteins. These were identified by GO analysis (http://www.geneontology.org/).

Subcellular location of each identified protein was assigned. We found most of the proteins localized in plasma membrane (31), extracellular (13), cytoplasm (11), mitochondria (10), nucleus (8), intracellular (5), cytoskeleton (8), and so forth. We are unable to find location of a large number of proteins that were assigned under unknown category (65) (novel or known) (Figure 4(a)).

On the basis of biological approach, the majority of proteins were scrutinized marked for their role in signal transduction, metabolism, cytoskeleton protein, transcription and translational regulation, energy pathways, regulation of blood coagulation cascade and intracellular trafficking and transport, stress response, and so forth (Figure 4(b)). 16 proteins fell within categories of signal transduction, 18 were categorized in electron carrier pathways, and so forth. Various housekeeping proteins were identified which act as cytoskeletal proteins like actin, myosin, tropomyosin, AGAP001799, and AGAP010147 playing a vital role in salivary gland. Proteins marked for chemosensory role were also found such as odorant-binding protein (OBP 52, OBPjj9, and OBP5470) and one hypothetical protein that has insect pheromone binding domain. Among D7 proteins (ancestral one, which was known to be originated from OBP proteins family), 6-cysteine and 10-cysteine residues are conserved and due to characteristic fold structure, they are distantly linked to OBP protein family $[23,24]$. Though their functions are varied like OBP role as an odorant carrier to the olfactory receptors and the function of $\mathrm{D} 7$ proteins has been projected to facilitate blood feeding by inhibiting hemostasis [25-27].

Various proteins that play an important role in immune responses were identified such as defensins, fibrinogen binding proteins (FBN9), majority of serine proteases, CLIPB (CLIPB 14, CLIPB 15, CLIPB 7, and CLIPB 13), serine protease 14, immune factor (rel homology domain), and lysozyme c6. Such proteins may also be responsible for reduction in microbial load in ingested blood. Among them defensin protein in An. stephensi was found to be $23 \%$ similar to An. gambiae protein. After analyzing with SMART programme, interestingly we also found Knotl domain which represents the antimicrobial peptides and has a role in defensive mechanism. In the salivary gland lysozyme c6 may help to check the bacterial growth in sugar meals of mosquitoes [28]. Various proteins involved in oxidoreductive process or stress response were also recognized like ND4L gene product, cytochrome 450 , glutathione S-transferases 3-8, glutathione S-transferase E1, and glutathione S-transferase E4. Among stress proteins heat shock protein (hsp DNA J) was the one that mainly helps in providing defense against various external stresses [29]. Several proteins were also identified by proteomic studies that were not described earlier by transcriptomics study in Anopheles stephensi such as proteins involved in signal transduction as STAT protein, SCRBQ2 protein, Anlar, STAT 1, calpain, TEP 2 protein, and others involved in transport such as tryptophan transporter, nicotinic acetylcholine receptor subunit $\beta 1$, and ACP receptor putative cation proton antiporter.

Long lists of enzymes were also identified that function as vasodilators, that is, peroxidases [30]. Three peroxidases enzymes, that is, peroxidase 1 , peroxidase 12 , and peroxidase 15, with $23-27 \%$ sequence similarity were identified. Even transcriptomics study also depicted 2 clusters of 12 sequences predict $80 \%$ sequences identical to An. gambiae [3]. Another enzyme which fell into antihemostatic category was salivary apyrases enzyme. The genes for these vasodilators or antihemostatic enzymes are expressed in the medial lobe and distallateral lobes of salivary gland [31-33]. This enzyme in insects is known to inhibit platelet aggregation by destroying the ATP and ADP released by activated platelets [31]. Transcriptomic studies of apyrase in An. stephensi also showed identity with salivary apyrase protein.

Among different tables some proteins with sequence coverage below $5 \%$ were identified which were actually not native proteins; in fact they are degraded product of the putative proteins.

3.3. Network Analysis of Known and Predicted Protein Interactions. We also presented the STRING network of some 


\begin{tabular}{|c|c|c|c|c|c|c|}
\hline 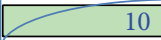 & 20 & 30 & 40 & 50 & 60 & 70 \\
\hline MKLLLLLASV & LCLALIVSAR & PSDETTDQES & STELSEDTSD & SYHQEEDTSE & TGADAGTEDG & NSEDDSSELE \\
\hline 80 & 90 & 100 & 110 & 120 & 130 & 140 \\
\hline SSSEEGHEDG & SEDATGEEGG & AGEKGEAGEE & DEAGEEGEAG & EEGEAGEEGG & AGEEGGAGEE & GGADEEGSAG \\
\hline 150 & 160 & 170 & 180 & 190 & 200 & 210 \\
\hline EEGGAEGGEE & SPVNTYHQVH & NLLK NIMNVG & TKNNYLKSFI & LARLQERLMN & PTIDLVGSIS & KYSKIKECFD \\
\hline 220 & 230 & 240 & 250 & 260 & 270 & \\
\hline SLADDVK SLV & 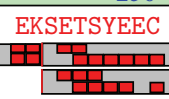 & $\begin{array}{ll}\text { SKDKNNPHCG } \\
4\end{array}$ & 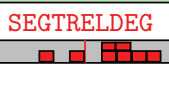 & 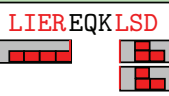 & 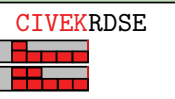 & \\
\hline
\end{tabular}

(a)

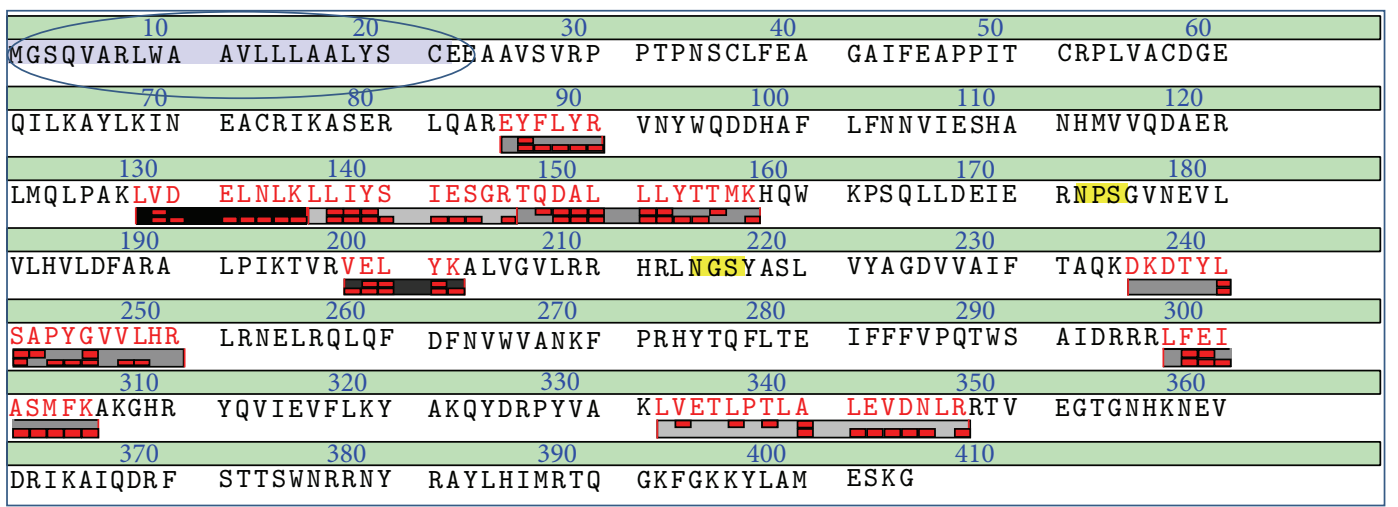

(b)

FIGURE 2: Annotated sequences of salivary protein precursors from An. stephensi. (a) GE rich salivary gland protein. The first 19 residues belong to the signal peptide of the precursor. (b) SG1D protein precursor. The first 24 residues belong to the signal peptide of the precursor.

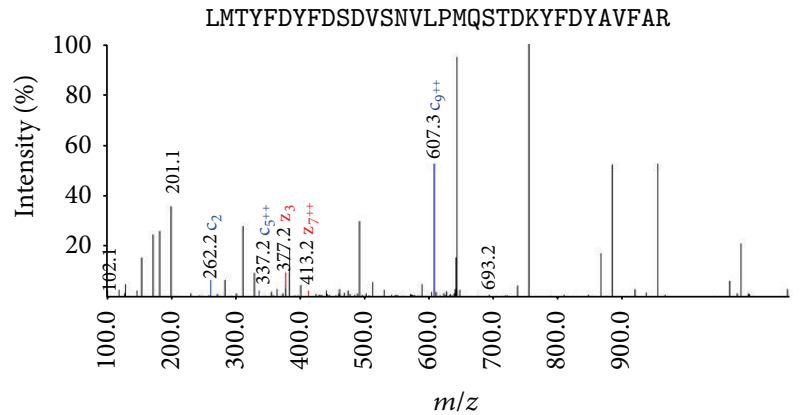

(a)

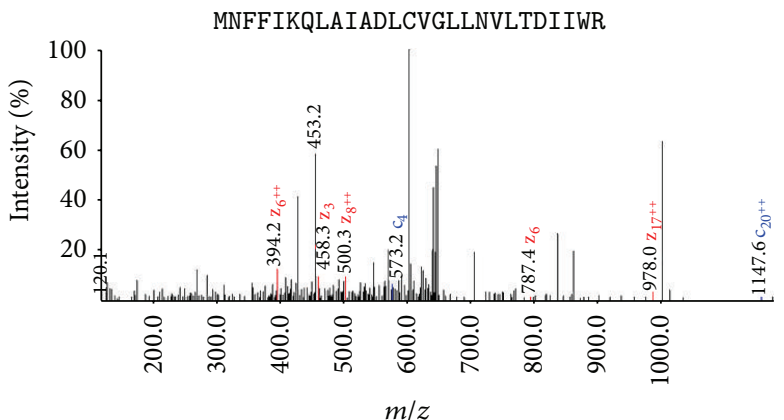

(b)

Figure 3: Peak spectrum analyzed by LC/MS/MS based on $\mathrm{m} / z$ values. (a) Peptide sequence (LMTYFDYFDSDVSNVLPMQSTDKYFDYAVFAR) with peak at $\mathrm{m} / z 470$ in An. stephensi corresponds to novel protein (hexamerin) of An. gambiae. (b) Peptide sequence (MNFFIKQLAIADLCVGLLNVLTDIIWR) with peak at $\mathrm{m} / z 638$ in An. stephensi corresponds to novel protein (G protein coupled receptor protein) of An. gambiae.

known/novel protein-protein interactions as an evidence view by using String 9.0 (Search Tool for the Retrieval of In-teracting Genes/Proteins) database of physical and functional interactions (http://string-db.org/) [34]. String 9.0 helps in predicting functional partners with a database of known and predicted protein interactions. Such proteinprotein interactions are further important for signaling pathways studies and modeling studies of complex proteins. Evidence view of novel thioredoxin protein $(21 \%$ similarity) identified by OMSSA algorithm was shown as interactions with other proteins, that is, glutaredoxin, superoxide dismutases, thioredoxin reductase, thioredoxin dependent peroxidases, and so forth (Figure 5(a)), which may predict further its significance in signaling pathways. Evidence view 

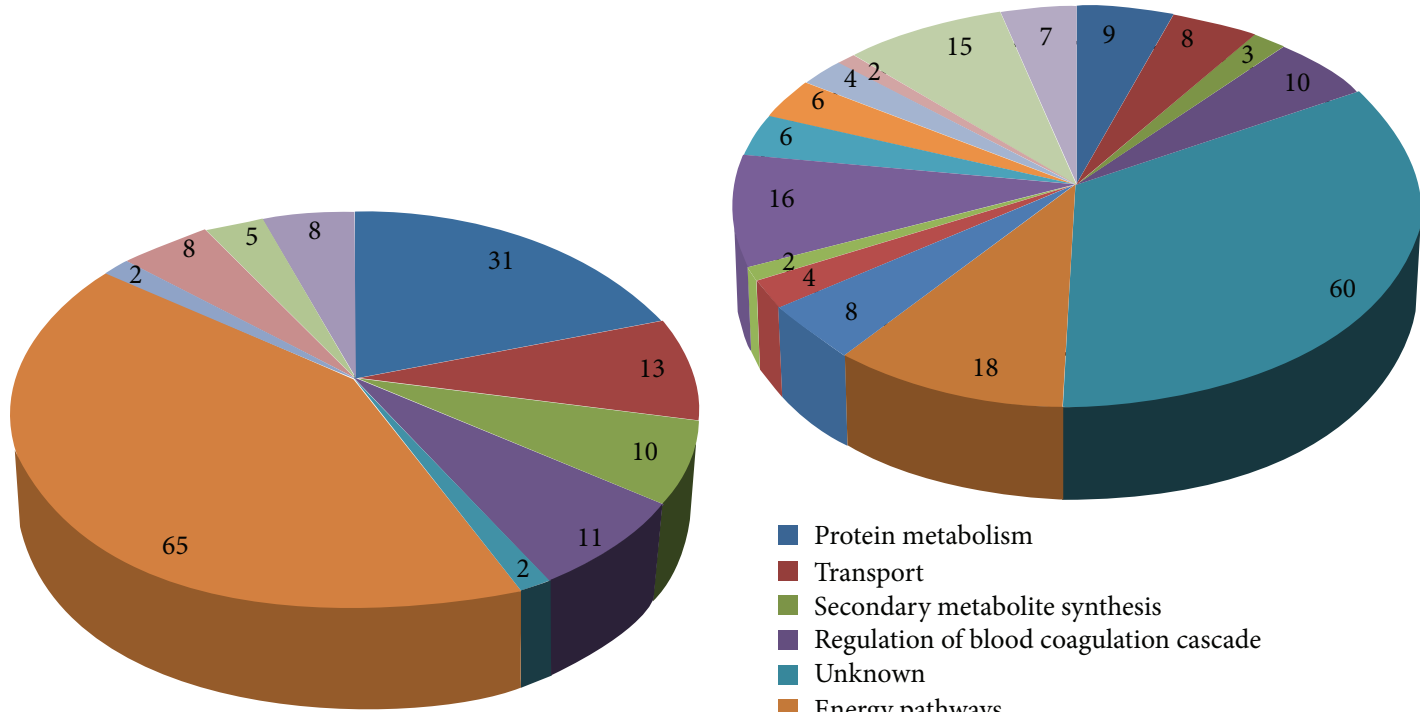

Protein metabolism

- Transport

- Secondary metabolite synthesis

- Regulation of blood coagulation cascade

Unknown

Energy pathways

Membrane
Extracellular
Mitochondria
Cytoplasm
Endosome
Unknown
Endoplasmic reticulum
Nucleus
Intracellular
Cytoskeleton

(a)
Regualtion of transcription factor

DNA replication

Amino acid transport and metabolism

- Signal transduction

Cell differentiation and apoptosis

- Cytoskeleton constituents

- Hydrolysis

Blood feeding

Immune response

Food digestion

FIGURE 4: Depiction of identified salivary proteins of An. stephensi using gene ontology tool. (a) Intracellular localization of proteins identified by Q-TOF-MS/MS. (b) Functional (putative) classification of identified known and novel proteins. The number of total identified proteins is marked.

of odorant-binding protein showed interaction with other odorant-binding proteins (OBP6, OBP1) and their precursors and protein O-fucosyltransferase 1 with other An. gambiae proteins (Figures 5(b) and 5(c)).

\section{Conclusions}

Mass spectrometric based proteomics techniques coupled with high throughput bioinformatic analysis are a powerful platform to understand comprehensive biology and interaction of functional proteins. Salivary gland proteins of the Anopheles mosquitoes are believed to be important in the development of the plasmodium as these molecules are involved in the antihemostatic activity, which may assist during the blood feeding process and play a critical role in the transmission of malaria parasite. Our idea was to analyze the putative functional role of the previously known and other novel salivary proteins that may be essential for parasite development in the mosquito directly or indirectly. Here, we report our initial studies using proteomic approaches to characterize the salivary gland proteomic repertoire of an urban malaria vector An. stephensi and its identification by searching protein sequence databases. For that, two different algorithms were used to identify the proteins or peptides from databases (NCBI nr, SwissProt), namely, MASCOT and OMSSA, and a total of 36 known proteins and 123 novel proteins were analyzed. These identified proteins were analyzed functionally (molecular and biological) by using bioinformatics software so that such salivary proteins can be further employed to understand the concept of feeding, insecticide resistance mechanisms, signal transduction, immunological properties, and various aspects of vectorparasite host interactions.

Such proteins may be used for development of novel antimalarial control strategies for improving innate protection against malaria and help to elucidate the various aspects of salivary gland-malaria parasite interactions.

\section{Conflict of Interests}

The authors declare that there is no conflict of interests regarding the publication of this paper.

\section{Authors' Contribution}

Sonam Vijay carried out the experiments, participated in the data analysis, and drafted the paper. Manmeet Rawat participated in interpretation of data. Arun Sharma helped 


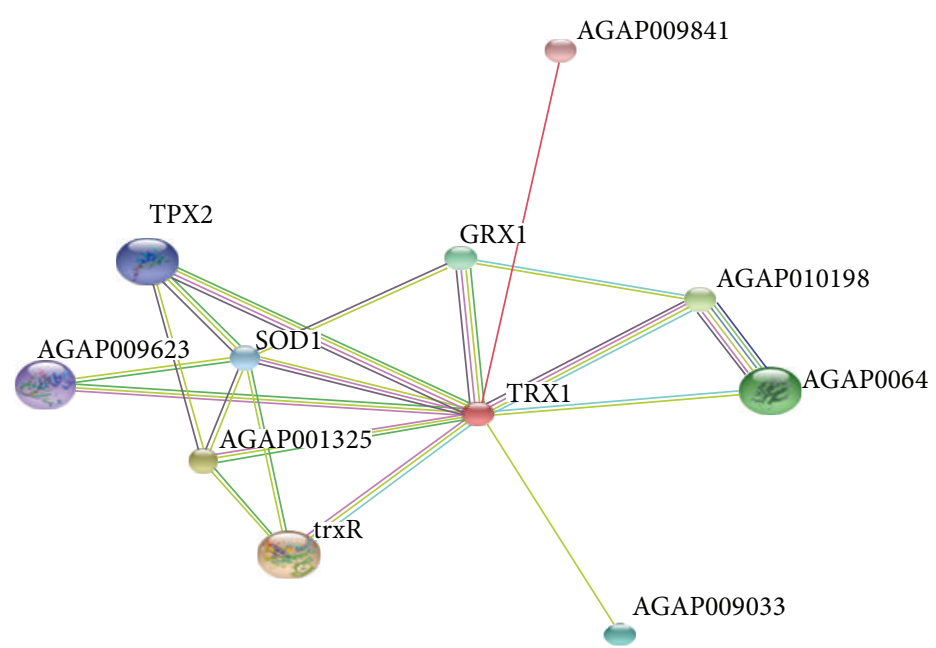

(a)

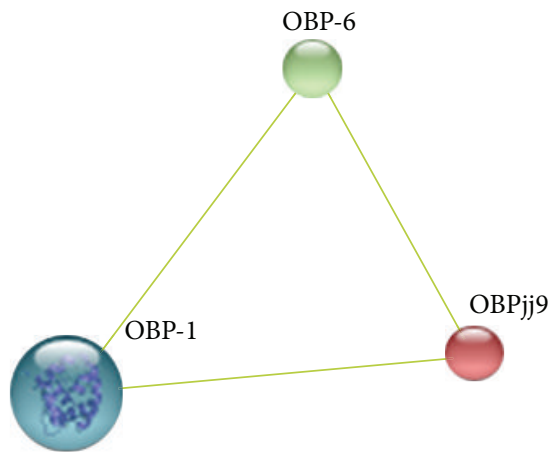

(b)

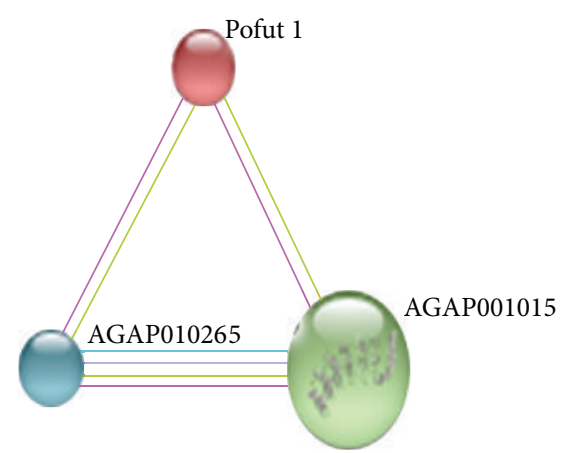

(c)

FIGURE 5: STRING network of protein-protein interactions identified by OMSSA algorithm. (a) Protein Q9NGZ1_ANOGA is shown as TRX1 (thioredoxin 1) in the network showing functional interactions with other proteins. (b) Protein Q7QCC4_ANOGA is shown as OBPjj9 (odorant-binding protein). (c) Protein Q7QHS7_ANOGA is shown as pofut1 (O-fucosyltransferase 1 protein). Different line colors represent the types of evidence for the association. Green color depicts neighborhood; red color: gene fusion; pink color: experiments; light green color: text mining; blue color: cooccurrence; dark blue color: coexpression; purple color: homology. Circle nodes indicated different proteins.

in design of the project, provided facilities and scientific environment for experimental work, and drafted the paper. All authors read and approved the final paper.

\section{Acknowledgments}

The authors would like to acknowledge their technical staff, Mr. Bhanu Arya (Technical Officer) and Mrs. Poonam Gupta (Technical Assistant), for their excellent technical help in proteomics experiments. This work has been financially supported by the National Institute of Malaria Research (Intramural), New Delhi, Government of India.

\section{References}

[1] WHO-World Health Organization, "World Malaria Report 2013," Tech. Rep., WHO, Geneva, Switzerland, 2013.
[2] A. K. Hati, "Urban malaria vector biology," Indian Journal of Medical Research, vol. 106, pp. 149-163, 1997.

[3] J. G. Valenzuela, I. M. B. Francischetti, V. M. Pham, M. K. Garfield, and J. M. C. Ribeiro, "Exploring the salivary gland transcriptome and proteome of the Anopheles stephensi mosquito," Insect Biochemistry and Molecular Biology, vol. 33, no. 7, pp. 717-732, 2003.

[4] J. M. C. Ribeiro, "Blood-feeding arthropods: live syringes or invertebrate pharmacologists?" Infectious Agents and Disease, vol. 4, no. 3, pp. 143-152, 1995.

[5] B. Arcà, F. Lombardo, J. G. Valenzuela et al., "An updated catalogue of salivary gland transcripts in the adult female mosquito, Anopheles gambiae," Journal of Experimental Biology, vol. 208, no. 20, pp. 3971-3986, 2005.

[6] A. Poinsignon, S. Cornelie, M. Mestres-Simon et al., "Novel peptide marker corresponding to salivary protein gSG6 potentially identifies exposure to Anopheles bites," PLoS ONE, vol. 3, no. 6, Article ID e2472, 2008. 
[7] P. F. Billingsley, J. Baird, J. A. Mitchell, and C. Drakeley, "Immune interactions between mosquitoes and their hosts," Parasite Immunology, vol. 28, no. 4, pp. 143-153, 2006.

[8] I. Djegbe, S. Cornelie, M. Rossignol et al., "Differential expression of salivary proteins between susceptible and insecticideresistant mosquitoes of Culex quinquefasciatus," PLOS ONE, vol. 6, no. 3, Article ID e17496, 2011.

[9] R. Dixit, A. Sharma, D. T. Mourya, R. Kamaraju, M. S. Patole, and Y. S. Shouche, "Salivary gland transcriptome analysis during Plasmodium infection in malaria vector Anopheles stephensi," International Journal of Infectious Diseases, vol. 13, no. 5, pp. 636-646, 2009.

[10] R. Dixit, M. Rawat, S. Kumar, K. C. Pandey, T. Adak, and A. Sharma, "Salivary gland transcriptome analysis in response to sugar feeding in malaria vector Anopheles stephensi," Journal of Insect Physiology, vol. 57, no. 10, pp. 1399-1406, 2011.

[11] D. E. Kalume, M. Okulate, J. Zhong et al., "A proteomic analysis of salivary glands of female Anopheles gambiae mosquito," Proteomics, vol. 5, no. 14, pp. 3765-3777, 2005.

[12] O. H. Lowry, N. J. Rosebrough, A. L. Farr, and R. J. Randall, "Protein measurement with the folin phenol reagent," The Journal of Biological Chemistry, vol. 193, no. 1, pp. 265-275, 1951.

[13] L. Y. Geer, S. P. Markey, J. A. Kowalak et al., "Open mass spectrometry search algorithm," Journal of Proteome Research, vol. 3, no. 5, pp. 958-964, 2004.

[14] J. M. C. Ribeiro and I. M. B. Francischetti, "Role of arthropod saliva in blood feeding: sialome and post-sialome perspectives," Annual Review of Entomology, vol. 48, pp. 73-88, 2003.

[15] B. F. Cravatt, G. M. Simon, and J. R. Yates III, "The biological impact of mass-spectrometry-based proteomics," Nature, vol. 450, no. 7172, pp. 991-1000, 2007.

[16] T. Köcher and G. Superti-Furga, "Mass spectrometry-based functional proteomics: from molecular machines to protein networks," Nature Methods, vol. 4, no. 10, pp. 807-815, 2007.

[17] A. Marchler-Bauer, J. B. Anderson, C. deWeese-Scott et al., "CDD: a curated Entrez database of conserved domain alignments," Nucleic Acids Research, vol. 31, no. 1, pp. 383-387, 2003.

[18] I. Letunic, R. R. Copley, S. Schmidt et al., "SMART 4.0: towards genomic data integration," Nucleic Acids Research, vol. 32, pp. D142-D144, 2004.

[19] T. N. Petersen, S. Brunak, G. Von Heijne, and H. Nielsen, "SignalP 4.0: discriminating signal peptides from transmembrane regions," Nature Methods, vol. 8, no. 10, pp. 785-786, 2011.

[20] B. Arcà, F. Lombardo, M. de Lara Capurro et al., "Trapping cDNAs encoding secreted proteins from the salivary glands of the malaria vector Anopheles gambiae," Proceedings of the National Academy of Sciences of the United States of America, vol. 96, no. 4, pp. 1516-1521, 1999.

[21] A. Lanfrancotti, F. Lombardo, F. Santolamazza et al., "Novel cDNAs encoding salivary proteins from the malaria vector Anopheles gambiae," FEBS Letters, vol. 517, no. 1-3, pp. 67-71, 2002.

[22] L. G. Fradkin, J. T. Kamphorst, A. DiAntonio, C. S. Goodman, and J. N. Noordermeer, "Genomewide analysis of the Drosophila tetraspanins reveals a subset with similar function in the formation of the embryonic synapse," Proceedings of the National Academy of Sciences of the United States of America, vol. 99, no. 21, pp. 13663-13668, 2002.

[23] B. J. Mans, E. Calvo, J. M. C. Ribeiro, and J. F. Andersen, “The crystal structure of D7r4, a salivary biogenic amine-binding protein from the malaria mosquito Anopheles gambiae," Journal of Biological Chemistry, vol. 282, no. 50, pp. 36626-36633, 2007.
[24] D. S. Hekmat-Scafe, R. L. Dorit, and J. R. Carlson, "Molecular evolution of odorant-binding protein genes $O S-E$ and $O S-F$ in Drosophila," Genetics, vol. 155, no. 1, pp. 117-127, 2000.

[25] P. X. Xu, L. J. Zwiebelt, and D. P. Smith, "Identification of a distinct family of genes encoding atypical odorant-binding proteins in the malaria vector mosquito, Anopheles gambiae," Insect Molecular Biology, vol. 12, no. 6, pp. 549-560, 2003.

[26] E. Calvo, B. J. Mans, J. F. Andersen, and J. M. C. Ribeiro, "Function and evolution of a mosquito salivary protein family," The Journal of Biological Chemistry, vol. 281, no. 4, pp. 19351942, 2006.

[27] S. Das, A. Radtke, Y. Choi, A. M. Mendes, J. G. Valenzuela, and G. Dimopoulos, "Transcriptomic and functional analysis of the Anopheles gambiae salivary gland in relation to blood feeding," BMC Genomics, vol. 11, no. 1, article 566, 2010.

[28] P. A. Rossignol and A. M. Lueders, "Bacteriolytic factor in the salivary glands of Aedes aegypti," Comparative Biochemistry and Physiology B, vol. 83, no. 4, pp. 819-822, 1986.

[29] A. A. Lund, D. M. Rhoads, A. L. Lund, R. L. Cerny, and T. E. Elthon, "In Vivo Modifications of the Maize Mitochondrial Small Heat Stress Protein, HSP22," Journal of Biological Chemistry, vol. 276, no. 32, pp. 29924-29929, 2001.

[30] J. M. C. Ribeiro and J. G. Valenzuela, "Purification and cloning of the salivary peroxidase/catechol oxidase of the mosquito Anopheles albimanus," The Journal of Experimental Biology, vol. 202, no. 7, pp. 809-816, 1999.

[31] D. E. Champagne, C. T. Smartt, J. M. C. Ribeiro, and A. A. James, "The salivary gland-specific apyrase of the mosquito Aedes aegypti is a member of the $5^{\prime}$-nucleotidase family," Proceedings of the National Academy of Sciences of the United States of America, vol. 92, no. 3, pp. 694-698, 1995.

[32] C. T. Smartt, A. P. Kim, G. L. Grossman, and A. A. James, "The Apyrase gene of the vector mosquito, Aedes aegypti, is expressed specifically in the adult female salivary glands," Experimental Parasitology, vol. 81, no. 3, pp. 239-248, 1995.

[33] N. Jariyapan, S. Roytrakul, A. Paemanee et al., "Proteomic analysis of salivary glands of female Anopheles barbirostris species A2 (Diptera: Culicidae) by two-dimensional gel electrophoresis and mass spectrometry," Parasitology Research, vol. 111, no. 3, pp. 1239-1249, 2012.

[34] L. J. Jensen, M. Kuhn, M. Stark et al., "STRING 8-a global view on proteins and their functional interactions in 630 organisms," Nucleic Acids Research, vol. 37, no. 1, pp. D412-D416, 2009. 

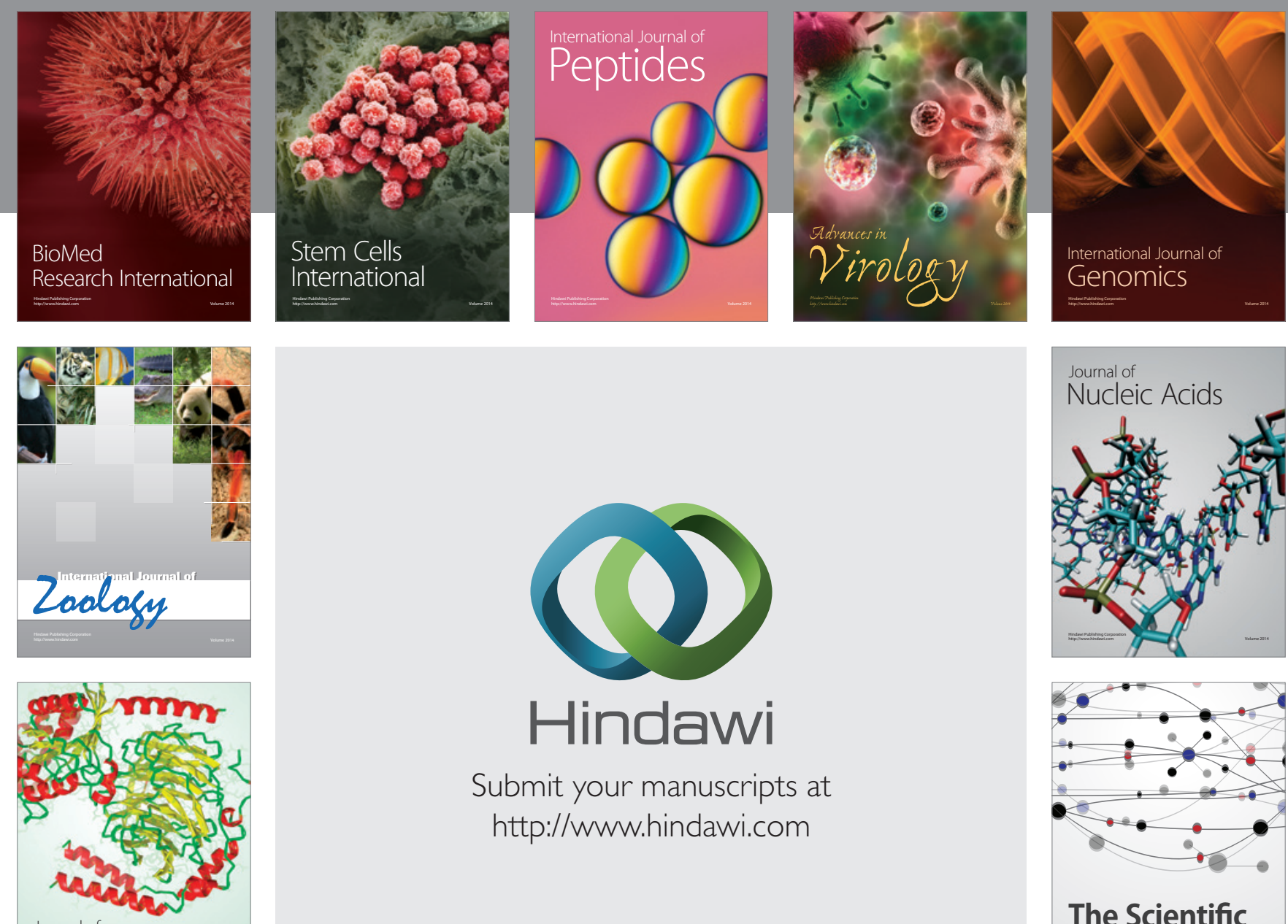

Submit your manuscripts at

http://www.hindawi.com

Journal of
Signal Transduction
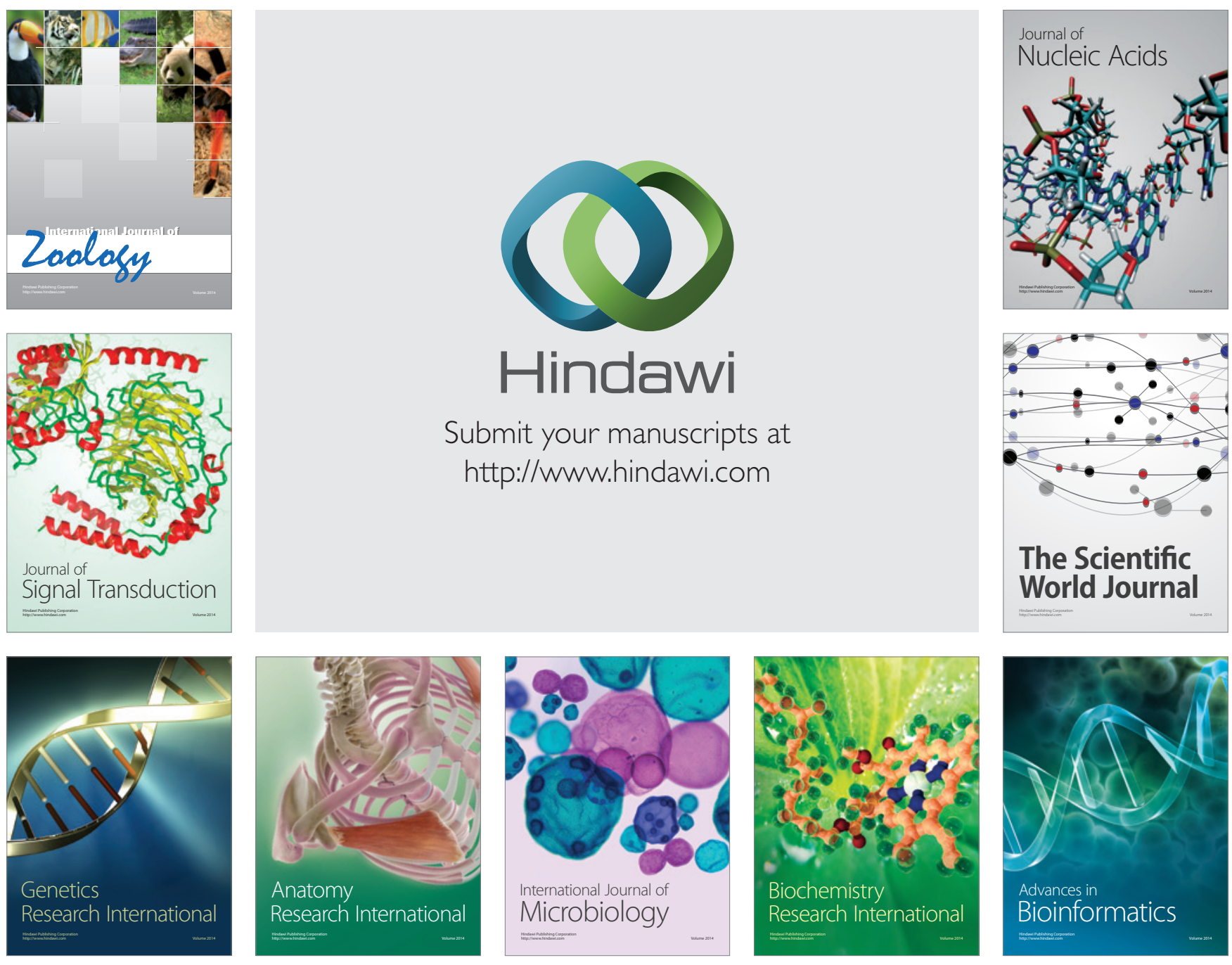

The Scientific World Journal
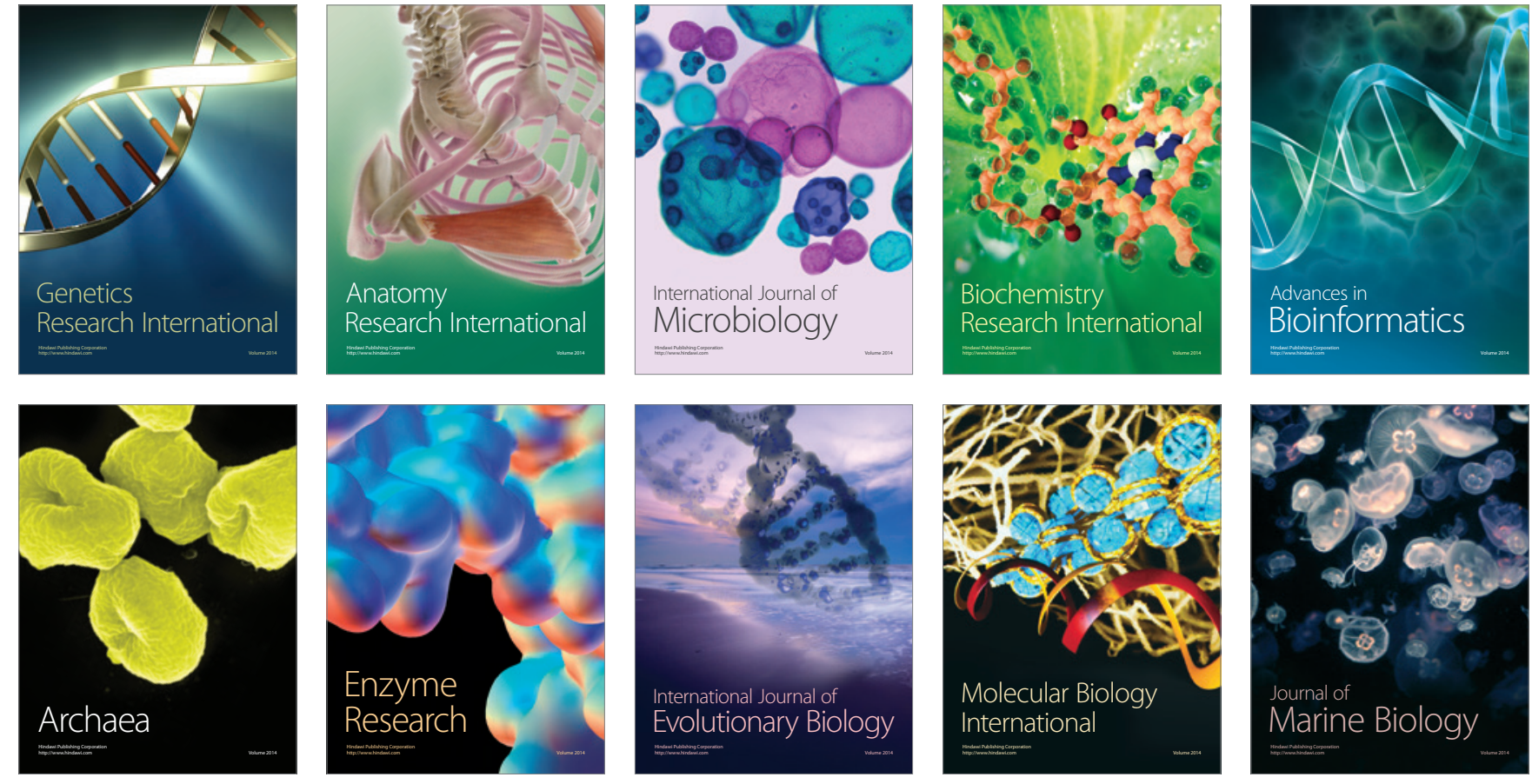